\title{
Accounting Conservatism and Managerial Excess Perks
}

\author{
Han $\mathrm{Li}^{1}$ \\ ${ }^{1}$ SILC Business School, Shanghai University, Shanghai, China \\ Correspondence: Han Li, SILC Business School, Shanghai University, 20 Chengzhong Road, JiaDing District, \\ Shanghai 201800, China. Tel: 86-21-6998-0028 ext.53101.
}

Received: February 11, 2019

Accepted: March 4, 2019

Online Published: March 11, 2019

doi:10.5430/afr.v8n2p32

URL: https://doi.org/10.5430/afr.v8n2p32

\begin{abstract}
This paper sheds light on the relationship between accounting conservatism and managerial excess perks. In general, there are two views about managerial perks, agency cost view and management incentive view. Under the assumption that considers managerial perks as agency costs, the abnormal managerial perks erode the value of firms. Accounting conservatism can significantly restrict the managerial excess perks. Due to the strict compensation regulation in China's SOEs, the negative relationship between accounting conservatism and excess perks in China's SOEs is stronger than in non-SOEs. Further, in the robustness tests, this paper finds that negative relationship is stronger in the firms of lower level accounting conservatism or higher level financial leverage.
\end{abstract}

Keywords: conservatism, perquisites, earnings management, managerial behaviour

\section{Introduction}

Managerial perks are defined as forms of nonmonetary compensation to selected employees (Rajan and Wulf, 2006). Different with explicit compensation, such as salary, bonus, etc., managerial perks as implicit compensation are not easily observed. Therefore, managerial perks sometimes are used as the manipulated accounting tools by some managers in order to increase or decrease the firms' earnings. In the prior researches, there are two mainstream theories for explaining the managerial perks. One is agency cost view, the other is incentive scheme view. For the agency cost view, managerial excess perks are the proofs of agency problems that the separated interests between shareholders as the principle and managers as the agent. Without higher quality of internal control or corporate governance, the managers can manipulate the financial reports on the purposes of increasing the value for themselves rather than the firms. This kind of myopic behaviors will erode the value of the firms and reduce the interests of shareholders. Especially when the firms have plenty of free cash flow, the managers are willing to expend more excess perks. However, for the incentive scheme view, managerial excess perks can be considered as the recovery of insufficient explicit compensation. The extra compensation as the form of managerial perks would motivate the managers to operate the firms more efficiently. Therefore, managerial excess perks in essence would increase the value of the firms due to the increased productivity. This paper is based on the selected Chinese listed firms. Prior research has found that the extent of marketization, the types of firms' ownership and the quality of corporate governance matter for the managerial excess perks (Hao et al.,2018; Zhai et al., 2015; Andrews et al. 2009). There are few researches to investigate whether the accounting conservatism principle matters for the managerial excess perks. This paper tries to fill in this gap. The results of this paper show that accounting conservatism is negatively associated with managerial excess perks. That means accounting conservatism can restrict the excess perks and increase the value of the firms. Further research demonstrates that in the state-owned enterprises (SOEs), the negative effect between accounting conservatism and managerial excess perks is larger than in the non-state-owned enterprises (non-SOEs). In the robustness part, the negative effect is also stronger in lower level accounting conservatism firms than in stronger level conservatism firms. The negative relationship between accounting conservatism and managerial excess perks is significant when the firm has higher level of financial leverage.

This paper contributes to the literature on accounting conservatism. It discusses the relationship between accounting conservatism and managerial perks. The research indicates that accounting conservatism can effectively restrict the managerial abnormal perks and increase the value of firms. This result helps regulators, professional managers and academicians fully understand the important role of accounting conservatism and enhance the internal control quality.

The remainder parts of this paper are organized as follows: Part 2 reports the literature review and hypothesis 
development; Part 3 describes the sample and measurement; Part 4 shows the research design and results; Part 5, conclusions; and the last part, reference.

\section{Literature Review and Hypothesis Development}

\subsection{Prior Research on Perquisites}

Perquisites or "perks" are referred to "forms of nonmonetary compensation offered to selected employees" (Rajan and Wulf, 2006). In the Merrianm-Webster Dictionary (2004), the perquisite is "an incidental payment, benefit, privilege, or advantage over and above regular income, salary, or wages". Compared with salary, bonus and stock option schemes in firms, perks are more unobservable. However, when the media discloses that some listed CEOs luxurious business activities, such as, using giant office rooms or incurring enormous amounts of entertainment and travel costs (ETCs), the public will be angry with these managerial behaviors. Since 2006, the Security and Exchange Commission (SEC) requests the listed firms in USA to release the executive compensation disclosure in which executive perks data are collected.

There are different viewpoints regards to the economic effects of executive perquisites. One side considers the perks as the proofs of agency problems (Jensen and Meckling, 1976). Managerial perks make the managers misuse of firm's resources. This is the cost viewpoint for managerial perks; The other side argues that the perks can play as the compensation incentive role (Fama, 1980), in other words, managerial perks encourage the managers to performance well and increase the value of the firm. This is the incentive viewpoints (Zhang, et al., 2015)

Agency problem

Jensen and Meckling (1976) argued that the interests conflicts exist between the managers as the agent and shareholders as the principle. The managerial perks could include subsidized meals and accommodation, travel and entertainment costs, etc. It is not easy to recognize whether the above consumption is necessary for the normal business purposes. Without strict corporate governance and better-quality internal control policies, the managers tend to consume the perks as much as they could. It is believed that the managerial perks are implicit compensation incentives. When the explicit compensation, such as salary or bonus scheme, is limited by the regulation of Board of Directors or governments, the managerial perks in fact become an alternative compensation. Because of information asymmetric problems, it is costly to accurately determine the performance of management teams and monitor the perks consumption. The management perks will reduce the value of the firms, and then further decrease the interests of shareholders (Adithipyangkul et al., 2009).

Jensen (1986) advocated that agency problems would easily arise when the firms have enormous free cash flows. Free cash flow is the cash flow in excess of the amounts necessary to finance all positive investment projects. The existence of agency problems causes many managerial short-term myopic behaviors, for example, managers have incentives to enlarge the firms' size beyond the optimal structure for increasing their own powers and benefits. Substantial free cash flow would easily cause overinvestment and managerial excess perks. More dividends payouts to shareholders will reduce the cash flows and resources in the firms and lower the managers' powers (Rozeff,1982; Easterbrook,1984). More dividends payment has the effect to reduce managerial excess perks. In sum, managerial perks can satisfy for the need of the managers, while they can erode the interests of shareholders (Hart,2001).

\section{Optimal Contract Incentive}

Contrary to Jensen's views, Fama (1980) argues that the managerial perks could be parts of the compensation incentive scheme. It implies that implicit managerial perks substitute for explicit cash compensation especially when cash compensation lacks for enough motivation for managers. Managers' compensation should be adjusted for the managerial performance. Managers will face more uncertainty situations in the markets. The total compensation for the managers should recover the whole risk that the managers endure. But it is not economic and realistic to negotiate the compensation contracts with the managers from time to time. The change of the cash compensation for managers does not accompany with the change of total risk that the managers endure on the same time. Therefore, the existence of managerial perks can be considered as the recovery of insufficient compensation which is under the acquiescence of Board of Directors because there is no need to frequently adjust the manager's explicit compensation (i.e. salary or bonus scheme). To some extent, Board of Directors allow the expenditure of managerial perks because of the large amounts of the agency costs. Similarly, the existence of firms' managerial perks also make sense in economies of scale when determining larger numbers of employees' compensation (Adithipyangkul et al.,2009). Furthermore, managerial perks as non-cash compensation has tax-free effects. Managers will pay personal income tax based on their explicit salary and bonus. In most times, the tax rate is accelerated with different levels of remunerations. Larger amounts of salary payments will be levied higher tax expenses from the remuneration of the 
mangers. The managers sometimes prefer to non-cash compensation because of no tax payments. The managerial perks expenditure can be expensed in firm's income statement. These are also tax shield effects for the firm's level. Moreover, managerial perks increase the utilities for the employees, supply more suitable working atmosphere, then increase the productivities and decrease the employees' turnover ratio. Under the incentive viewpoint, managerial perks have some advantages for increasing the value of the firms.

China's Specific Economic and Political Background

Current Chinese economic structure originated from centralized planned economies. Before the economic reform and open-door to overseas policies carried out, the managers in China's firms are only responsible for the production. The governments determined the supplies of materials and the sales of products. The cash compensation for the managers was relatively small. The compensation package for the managers is determined by the government's plans rather than the markets. The gap of cash compensation between the managers and employees is also small. The moral praise and honor play more important roles. However, with the gradual movement from the planned economies towards the market driven economies in China, the managers' performance is evaluated more by the productivity of the firm. The managers have more and more powers in controlling the resources in the firms. However, there are still many different features of firms between China and other more matured market-driven economies. Unlike other developed countries, the majority listed firms in China are stated-own companies (SOEs). The executives in SOEs are more like political officers rather than the professional managers in the job markets. Moreover, the objectives of SOEs are multiple choices, such as contribution for local region's GDPs, employment rates and other social duties rather than only for the maximization of firms' wealth. The managers' compensation packages in SOEs are designed and supervised by the governments. The managers normally cannot negotiate frequently with the firms. They can only accept the compensation packages. According to the definition of Jensen (1986), the compensation package consists of explicit compensation, such as salary, bonus, stock option scheme, and implicit compensation, such as career promotion, fringe benefits and managerial perks. In China's SOEs, the amounts of explicit compensation for the managers are supervised and limited. The political promotion and managerial perks in fact become the important components of managerial incentive schemes. The research of Zhang et al. (2015) gives the evidences of the incentive view of managerial perks. Although Cai et al. (2011) find some kinds of managerial perks have positive effects on the value of firms, there are more evidences that managerial perks, such as entertainment and travel costs overall have a negative relationship with firm productivity. Zhang et al. (2015) investigate the samples of listed firms in China and find managerial perks are more severe in private-controlled firms rather in state-owned firms; Managerial perks are positively associated with firms' growth and have a negative relationship with firms' size. The ownership concentration matters for the managerial perks.

\subsection{Research on Accounting Conservatism}

Accounting principles include objective, materiality, reliability and comparability, etc. Nowadays, accounting conservatism principle has attracted more academicians to research. Basu (1997) believes that accounting conservatism is to recognize the bad news quicker than good news. The expected unfavorable outcome is recognized promptly, while the expected favorable outcome is recognized later. In other words, the more verification of favorable outcome is needed. Furthermore, accounting conservatism is applied in many accounting standards, such as, $R \& D$ costs capitalized as assets under strict conditions (Note 1), accelerated depreciation methods, recognization of provision for doubtful debts and contingent liabilities, etc. The understated assets in balance sheet are associated with deferring recognization of earnings in income statement. The application of accounting conservatism can avoid the assets and incomes overvalued (Givoly et al., 2007).

Many researches investigate the contribution reasons to the conservatism principle and economic effects of the accounting conservatism. Some researches discuss the accounting conservatism relates to the audit (Basu, et al., 2001a; Gul, et.al., 2002). Beekes, et al. (2004) find accounting conservatism relates to board composition. Francis et al. (2004) describes its impacts on cost of financing. Hsu, et al. (2017) argue that accounting conservatism mitigate the drawbacks of CEO overconfidence.

Accounting conservatism consists of two forms: conditional conservatism and unconditional conservatism. Conditional conservatism is the different recognization of net income and assets with asymmetric information of timeliness (Basu, 1997). Unconditional conservatism is persistently downwards estimation of net income and assets. The external market information would not influence unconditional conservatism (Givoly and Hayn, 2000; Krishnan and Visvanthan, 2008). In this paper, accounting conservatism is measured as conditional conservatism. 


\subsection{Hypotheses Development}

In the prior literature, there are different viewpoints about the managerial perks: cost views and incentive views. To achieve the designed sales budgets and market shares, it is necessary to consume corresponding expenses in selling and administrative activities. However, to spend too much expenditure than normal level is a common phenomenon in China. It is reported that the amounts of managers' perks are 10 times of their explicit compensation. The ratio of voluntary disclosure of managerial perks is less than $40 \%$ in China (Chen et al., 2005). For most SOEs in China, the concentration ratio of shareholders' ownership is high and insider control is common. The managers have the powers to influence the financial reporting quality. Therefore, excess over the normal managerial perks could be mixed and hided into other periodic expenditure. The excess managerial perks belong to the agency problems that would erode the interests of shareholders. Due to the strict compensation regulation in SOEs, the explicit compensation package for the managers are rigid, then managerial perks as the implicit compensation make up for the insufficient explicit compensation. The managers have motivations to manipulate earnings through managerial perks.

Prior researches already find that several ways to restrain the drawbacks of excess managerial perks. External supervision policies, such as government regulation policy on managerial perks, significantly limit the perquisite consumption. This effect is higher in low marketization regions in China (Hao et al.,2018). Similar in U.S., the SEC amended the executive compensation disclosure rules in 2006, it is found that this mandatory requirement helps the market investors detect the possible excess consumption and misuse of firm's resources. Public media has also effectively inhibited abnormal managerial perks. The media monitoring function is more significant in more competitive areas (Zhai et al., 2015). Moreover, corporate governance also matters for managerial perks. Andrews et al. (2009) find that more managerial perks are awarded in weakly governed firms. It is believed that dividend payout in SOEs can reduce the free cash flows in the firms and further decrease the possibilities that managers consume in managerial perks. The payout of dividend requires the firms to continuously finance the funds from external financial markets. More external investors will involve into the firms' financing and investment decisions. The external investors will play the supervision roles. Luo and huang (2008) advocate that dividend policy can significantly restrain the consumption of managerial perks.

Jensen (1986) believes that more free cash flows motivate the mangers to over-invest the funds and spend more on managerial perks. However, under accounting conservative principle, the managers cannot freely manipulate the gains and enlarge the free cash flows. Fewer resources that managers can control will lead to fewer possibilities of excess managerial perks. Furthermore, accounting conservatism would convince debtors and shareholder that the firms' financial reporting quality is good. Then these activities would benefit for the lower cost of financing in financial markets. In this paper, the hypothesis is as follows:

Hypothesis 1: Accounting conservatism can restrain the abnormal managerial perks. In other words, there is negative relation between accounting conservatism and abnormal managerial perks.

Agency problem exists in both SOEs and non-SOEs. In SOEs, managers are considered as the agency, while shareholders are considered as the principle. The separation between the principle and the agency is the origin of agency problems. In general, the purposes of managers are more short-term oriented. More information asymmetric situations exist in firms, more serious agency problems will be. With the higher concentration ratio of ownership of shareholders and regulation on compensation in SOEs, agency problems in SOEs would induce more over-investment and more excess managerial perks. However, in non-SOEs, agency problems mainly give rise to transfer the wealth from the diversified ownership shareholders to controlling ownership shareholders. Unlike SOEs in China, managerial excess perks are not the major agency problems in non-SOEs. The effect of accounting conservatism restricted the abnormal perks in SOEs is larger than the effect in non-SOEs. Therefore, in this paper, another assumption is as follows:

\section{Hypothesis 2}

The negative relationship between accounting conservatism and abnormal managerial perks would be more significant in SOEs than in non-SOEs.

\section{Sample and Measurement about the Main Variable}

All accounting information is based on China's CSMAR database. The firms are selected from Shanghai and ShenZhen Stock markets. The data of firms is adapted from 2009 and 2012.Before the regression process, any firm that belongs to financial institutes or ST firms is deleted. Stata software is used for the statistics analysis. 


\subsection{Dependent Variable}

In this paper, the variable of abnormal managerial perks is adapted from the similar method of Luo (2011). Managerial perks are based on the firm's assets, the growth of sales, investment in property, plant and equipment (PPE) and financial investment and numbers of employee. See model (1)

$\frac{\text { Perks }_{t}}{\text { Assets }_{t-1}}=\beta_{0}+\beta_{1} \frac{1}{\text { Asset }_{t-1}}+\beta_{2} \frac{\Delta \text { sales }_{t}}{\text { Asset }_{t-1}}+\beta_{3} \frac{\text { PPE }_{t}}{\text { Assets }_{t-1}}+\beta_{4} \frac{\text { Inv }_{t}}{\text { Asset }_{t-1}}+\beta_{5}$ LnEmployee $_{\text {Lethel }} \quad$ Model (1)

The abnormal perks are the residual value by the regression of model (1).

\subsection{Independent Variable}

\section{Conservatism proxy}

\section{CONSER_Score}

this paper follows the methods of Basu (1997), Khan and Watts (2009) and García et al.(2016). The accounting conservatism proxy CONSER_Score is constructed with the following steps:

Basu's model: $\frac{E P S_{i, t}}{P_{i, t-1}}=\beta_{0}+\beta_{1} D R_{i, t}+\beta_{2} \operatorname{Ret}_{i, t}+\beta_{3} D R_{i, t} \times \operatorname{Ret}_{i, t}+\varepsilon_{i, t} \quad$ Model

Based on model (2), $\beta_{2}$ and $\beta_{3}$ are replaced by model (3) and model (4) respectively.

$$
\begin{aligned}
& G_{-} \text {Score }=\beta_{2}=\mu_{1}+\mu_{2} \text { Size }_{i, t}+\mu_{3} M B_{i, t}+\mu_{4} \text { Lev }_{i, t} \quad \text { Model } \\
& C_{-} \text {Score }=\beta_{3}=\lambda_{1}+\lambda_{2} \text { Size }_{i, t}+\lambda_{3} M B_{i, t}+\lambda_{4} \text { Lev }_{i, t} \quad \text { Model }
\end{aligned}
$$

The regression coefficient of the new equation is to estimate the extent of firms' accounting conservatism. The accounting conservatism proxy is the total sum of $G \_S c o r e$ and $C \_S c o r e$.

Control Variable

Size

Firm's Size, the natural logarithm of total assets

CFORatio Cash flows ratio, the ratio of cash flow this year divided by last year's assets

SalesGrowth Sales Growth, the ratio of sales this year divided by last year's assets

Lev Financial leverage, the total debts this year divided by last year's assets

State Dummy variable, 1 for SOEs, while 0 for non-SOEs

LnAge Firm's age, the natural logarithm of firm's age

Largest Largest shareholders ownership ratio

LnBoard Logarithm of the number of members in BoDs

Indep Percentage of the number of independent directors in BoDs

FthreeExComp The first three executive compensation

Mhold Percentage of shareholders by management

\section{Research Design and Results}

\subsection{Descriptive Data and Correlation Analysis}

\subsubsection{Descriptive Analysis}

Table 1 shows the summary information from the selected sample firms. The dependent variable AbnormalPerk is from -252 to 6050 . This means the managerial excess perks in Chinese listed firms varies a lot from different firms. The higher standard deviation also testifies the same result. The mean of testable variable CONSER_Score is 0.03. The range of CONSER_Score is from -0.01 to 0.77 . The standard deviation of CONSER_Score is 0.04 that means small variance for the variable. 
Table 1. Descriptive Analysis

\begin{tabular}{lccccc}
\hline \multicolumn{1}{c}{ Variable } & Obs & Mean & Std.Dev. & Min & Max \\
\hline AbnormalPerk* & 1516 & 267.00 & 584.00 & -252.00 & 6050.00 \\
CONSER_Score & 1458 & 0.03 & 0.04 & -0.01 & 0.77 \\
Size & 1516 & 21.81 & 1.33 & 18.15 & 25.77 \\
CFORatio & 1516 & -0.47 & 20.76 & -807.99 & 9.50 \\
SalesGrowth & 1516 & 1.37 & 20.80 & -1.00 & 675.77 \\
Lev & 1516 & 0.59 & 0.72 & 0.01 & 13.71 \\
State & 1516 & 0.68 & 0.47 & 0.00 & 1.00 \\
lnAge & 1516 & 2.61 & 0.19 & 1.61 & 3.09 \\
Largest & 1516 & 34.14 & 15.51 & 3.62 & 89.41 \\
lnBoard & 1516 & 2.18 & 0.20 & 1.39 & 2.89 \\
Indep & 1516 & 0.37 & 0.06 & 0.20 & 0.71 \\
FthreeExComp* & 1516 & 1.51 & 1.55 & 0.00 & 17.70 \\
Mhold & 1516 & 0.00 & 0.01 & 0.00 & 0.29 \\
\hline
\end{tabular}

AbnormalPerk and FthreeExComp are both measured as 1 million unit.

\subsubsection{Correlation Analysis}

The correlation matrix for all related variables is listed in appendix table 2. From the table 2, it shows that dependent variable AbnormalPerk is negatively correlated with testable variable CONSER_Score. The correlation coefficient between AbnormalPerk and CONSER_Score is -0.201. Further, the table 2 also describes that AbnormalPerk also negatively correlates with SalesGrowth (-0.024) and lnAge (-0.041).

Table 2. Correlation Matrix

\begin{tabular}{|c|c|c|c|c|c|c|c|c|c|c|c|c|c|}
\hline & AbnormalPerk & CONSER_Score & Size & CFORatio & SalesGrowth & Lev & State & lnAge & Largest & lnBoard & Indep & FthreeExComp & Mhold \\
\hline AbnormalPerk & 1.000 & & & & & & & & & & & & \\
\hline CONSER_Score & -0.201 & 1 & & & & & & & & & & & \\
\hline CFORatio & 0.012 & -0.001 & -0.008 & 1 & & & & & & & & & \\
\hline SalesGrowth & -0.024 & 0.009 & 0.007 & 0.005 & 1 & & & & & & & & \\
\hline Lev & 0.022 & 0.929 & -0.043 & -0.005 & 0.013 & 1 & & & & & & & \\
\hline lnAge & -0.041 & 0.079 & -0.064 & -0.022 & 0.041 & 0.060 & -0.103 & 1 & & & & & \\
\hline Largest & 0.171 & -0.157 & 0.274 & -0.072 & 0.080 & -0.059 & 0.162 & -0.130 & 1 & & & & \\
\hline $\operatorname{lnBoard}$ & 0.163 & -0.059 & 0.266 & -0.002 & 0.000 & 0.043 & 0.181 & -0.034 & -0.004 & 1 & & & \\
\hline Indep & 0.048 & -0.014 & 0.038 & 0.018 & -0.025 & 0.002 & -0.056 & 0.014 & 0.026 & -0.326 & 1 & & \\
\hline FthreeExComp & 0.348 & -0.154 & 0.441 & -0.011 & 0.037 & 0.012 & 0.072 & 0.079 & 0.021 & 0.147 & -0.023 & 1 & \\
\hline Mhold & 0.067 & -0.026 & 0.025 & 0.003 & -0.004 & -0.016 & -0.084 & -0.039 & -0.079 & 0.016 & 0.006 & 0.089 & 1 \\
\hline
\end{tabular}

4.2 Multivariate Regression Analysis

Table 1 tests the association between accounting conservatism and abnormal managerial perks. The regression is based on the equation of Model 5. The dependable variable in this table is AbnormalPerk that follows the method of Luo (2011). The testable variable is the proxy of accounting conservatism CONSER_Score. The column (1) of table 3 shows that CONSER_Score is negative associated with AbnormalPerk, the significant level is $99 \%$. This result consists with the hypothesis 1 that is accounting conservatism can restrain managerial excess perks. The column (2) of table 3 is the regression result when the firms belong to SOEs and the column (3) of table 3 is the regression result when the firms is non-SOEs. In the column (2), the coefficient of CONSER_Score is $-6.962 \mathrm{e}+10$, while in the column (3), the coefficient of CONSER_Score is just $-2.710 \mathrm{e}+10$. It is obvious that in SOEs, the effect that accounting conservatism restricts abnormal perks are stronger than non-SOEs. This prediction is the same as the hypothesis 2 that the negative relationship between accounting conservatism and abnormal managerial perks would be more significant in SOEs than in non-SOEs.

AbPerks $_{\mathrm{i}, \mathrm{t}}=\alpha_{0}+\alpha_{1}$ CONSER_Score $_{\mathrm{i}, \mathrm{t}}+\alpha_{2}$ Size $_{\mathrm{i}, \mathrm{t}}++\alpha_{3}$ CFORatio $_{\mathrm{i}, \mathrm{t}}+\alpha_{4}$ SalesGrowth $_{\mathrm{i}, \mathrm{t}}+\alpha_{5} \operatorname{Lev}_{\mathrm{i}, \mathrm{t}}+\alpha_{6}$ State $_{\mathrm{i}, \mathrm{t}}+\alpha_{7}$ LnAge $_{\mathrm{it}}$ $+\alpha_{8}$ Largest $_{\mathrm{it}}+\alpha_{9}$ LnBoard $_{\mathrm{it}}+\alpha_{10}$ IndeP $_{\mathrm{i}, \mathrm{t}}+\alpha_{11}$ FthreeExComp $_{\mathrm{i}, \mathrm{t}}+\alpha_{12}$ Mhold $_{\mathrm{it}}+\varepsilon$

(Model 5) 
In SOEs in China, the governments play the role as the principles, while the managers are similar as the agents. The agency problems in managerial excess perks are more severe in SOEs than in non-SOES. Therefore, the results of table 3 shows that accounting conservatism in the SOEs can effectively play the role on constraining the managerial excess perks.

Table 3. Regression analysis

\begin{tabular}{|c|c|c|c|}
\hline VARIABLES & $\begin{array}{c}(1) \\
\text { AbnormalPerk } \\
\text { Full Samples }\end{array}$ & $\begin{array}{c}(2) \\
\text { AbnormalPerk } \\
\text { SOEs }\end{array}$ & $\begin{array}{c}(3) \\
\text { AbnormalPerk } \\
\text { Non-SOEs }\end{array}$ \\
\hline CONSER_score & $\begin{array}{c}-5.620 \mathrm{e}+10 * * * \\
(1.062 \mathrm{e}+10)\end{array}$ & $\begin{array}{c}-6.962 \mathrm{e}+10 * * * \\
(1.576 \mathrm{e}+10)\end{array}$ & $\begin{array}{c}-2.710 \mathrm{e}+10 \text { *** } \\
(8.683 \mathrm{e}+09)\end{array}$ \\
\hline Size & $\begin{array}{c}-4.282 \mathrm{e}+08 * * * \\
(1.117 \mathrm{e}+08)\end{array}$ & $\begin{array}{c}-5.195 \mathrm{e}+08 * * * \\
(1.667 \mathrm{e}+08)\end{array}$ & $\begin{array}{c}-1.971 \mathrm{e}+08 * * \\
(9.152 \mathrm{e}+07)\end{array}$ \\
\hline CFORatio & $\begin{array}{c}-2,005 \\
(284,163)\end{array}$ & $\begin{array}{l}-1.836 e+07 \\
(2.364 e+07)\end{array}$ & $\begin{array}{c}-49,919 \\
(147,626)\end{array}$ \\
\hline SalesGrowth & $\begin{array}{l}-449,399 \\
(290,403)\end{array}$ & $\begin{array}{c}-1.136 \mathrm{e}+06^{*} \\
(689,250)\end{array}$ & $\begin{array}{l}-111,571 \\
(170,710)\end{array}$ \\
\hline Lev & $\begin{array}{c}3.048 \mathrm{e}+09 * * * \\
(5.703 \mathrm{e}+08)\end{array}$ & $\begin{array}{c}3.803 \mathrm{e}+09 * * * \\
(8.464 \mathrm{e}+08)\end{array}$ & $\begin{array}{c}1.472 \mathrm{e}+09 * * * \\
(4.669 \mathrm{e}+08)\end{array}$ \\
\hline State & $\begin{array}{c}8.361 \mathrm{e}+06 \\
(3.362 \mathrm{e}+07)\end{array}$ & & \\
\hline $\ln \mathrm{Age}$ & $\begin{array}{c}6.003 \mathrm{e}+07 \\
(1.240 \mathrm{e}+08)\end{array}$ & $\begin{array}{c}1.359 \mathrm{e}+08 \\
(1.677 \mathrm{e}+08)\end{array}$ & $\begin{array}{c}1.080 \mathrm{e}+08 \\
(9.672 \mathrm{e}+07)\end{array}$ \\
\hline Largest & $\begin{array}{c}-548,901 \\
(1.018 \mathrm{e}+06)\end{array}$ & $\begin{array}{c}1.308 \mathrm{e}+06 \\
(1.447 \mathrm{e}+06)\end{array}$ & $\begin{array}{c}-2.663 \mathrm{e}+06^{* * * *} \\
(902,506)\end{array}$ \\
\hline $\operatorname{lnBoard}$ & $\begin{array}{c}9.813 \mathrm{e}+07 \\
(6.867 \mathrm{e}+07)\end{array}$ & $\begin{array}{c}7.513 e+07 \\
(1.009 e+08)\end{array}$ & $\begin{array}{c}2.128 \mathrm{e}+07 \\
(5.679 \mathrm{e}+07)\end{array}$ \\
\hline Indep & $\begin{array}{c}2.185 \mathrm{e}+08 \\
(1.732 \mathrm{e}+08)\end{array}$ & $\begin{array}{l}4.095 \mathrm{e}+08^{*} \\
(2.445 \mathrm{e}+08)\end{array}$ & $\begin{array}{c}-3.940 \mathrm{e}+08^{* *} \\
(1.604 \mathrm{e}+08)\end{array}$ \\
\hline FthreeExComp & $\begin{array}{c}60.52 * * * \\
(7.366)\end{array}$ & $\begin{array}{c}60.14 * * * \\
(9.391)\end{array}$ & $\begin{array}{c}54.42 * * * \\
(8.783)\end{array}$ \\
\hline Mhold & $\begin{array}{l}-1.892 \mathrm{e}+08 \\
(7.129 \mathrm{e}+08)\end{array}$ & $\begin{array}{c}9.919 \mathrm{e}+09 \\
(7.041 \mathrm{e}+09)\end{array}$ & $\begin{array}{l}-3.325 e+07 \\
(5.552 e+08)\end{array}$ \\
\hline Industry & Yes & Yes & Yes \\
\hline Year & Yes & Yes & Yes \\
\hline Constant & $\begin{array}{c}9.068 \mathrm{e}+09 * * * \\
(2.502 \mathrm{e}+09)\end{array}$ & $\begin{array}{c}1.078 \mathrm{e}+10 * * * \\
(3.681 \mathrm{e}+09)\end{array}$ & $\begin{array}{c}4.259 \mathrm{e}+09 * * \\
(2.031 \mathrm{e}+09)\end{array}$ \\
\hline Observations & 1,458 & 1,005 & 453 \\
\hline Number of ID & 374 & 268 & 129 \\
\hline
\end{tabular}

Standard errors in parentheses

$* * * \mathrm{p}<0.01, * * \mathrm{p}<0.05, * \mathrm{p}<0.1$

4.3 Robustness Tests

4.3.1 High versus Low Accounting Conservatism Level

In this paper, based on the different levels of accounting conservatism, the effects of constraining of abnormal excess perks are different. First, when CONSER_Score is more than 95\% percentile of CONSER_Score (0.056642), the firms are believed as higher level of accounting conservatism; while, if CONSER_Score is less than 75\% percentile 
of CONSER_Score (0.0392071), the firms are considered as lower level of accounting conservatism. This research finds that the effects that accounting conservatism constrains managerial excess perks are stronger under the less accounting conservatism firms compared with under higher level of accounting conservatism firms. It means that abnormal perks easily occur in the firms of lower internal control quality, less information disclosure. After applying for accounting conservatism in these firms, the managerial excess perks can be significantly reduced. In table 4, the column (1) reflects the negative relation between CONSER_Score and AbnormalPerk when the firms have lower level of CONSER_Score, the significant level is 99\% ( $<<0.01$ ), the coefficient of CONSER_Score is $-9.107 \mathrm{e}+10$. The column (2) still shows the negative association between the testable variable CONSER_Score and dependent variable AbnormalPerk. But the coefficient of CONSER_Score is only $-2.904 \mathrm{e}+10$. It confirms that accounting conservatism has more influences on managerial excess perks in the firms of lower level conservatism.

Table 4. Regression analysis

\begin{tabular}{|c|c|c|}
\hline \multirow{3}{*}{ VARIABLES } & (1) & (2) \\
\hline & AbnormalPerk & AbnormalPerk \\
\hline & Low CONSER_Score & High CONSER_Score \\
\hline \multirow[t]{2}{*}{ CONSER_Score } & $-9.107 \mathrm{e}+10 * * *$ & $-2.904 \mathrm{e}+10 * * *$ \\
\hline & $(2.214 e+10)$ & $(6.394 e+09)$ \\
\hline \multirow[t]{2}{*}{ Size } & $-6.692 \mathrm{e}+08 * * *$ & $-2.438 \mathrm{e}+08 * * *$ \\
\hline & $(2.386 \mathrm{e}+08)$ & $(6.372 \mathrm{e}+07)$ \\
\hline \multirow[t]{2}{*}{ CFORatio } & $-58,789$ & $3.055 \mathrm{e}+07$ \\
\hline & $(325,674)$ & $(8.647 \mathrm{e}+07)$ \\
\hline \multirow[t]{2}{*}{ SalesGrowth } & $-389,567$ & $-1.098 \mathrm{e}+06$ \\
\hline & $(376,535)$ & $(1.560 \mathrm{e}+06)$ \\
\hline \multirow[t]{2}{*}{ Lev } & $4.549 \mathrm{e}+09 * * *$ & $1.578 \mathrm{e}+09 * * *$ \\
\hline & $(1.213 \mathrm{e}+09)$ & $(3.454 \mathrm{e}+08)$ \\
\hline \multirow[t]{2}{*}{ State } & $1.153 e+07$ & $-1.236 e+07$ \\
\hline & $(4.871 \mathrm{e}+07)$ & $(1.922 \mathrm{e}+07)$ \\
\hline \multirow[t]{2}{*}{$\ln A g e$} & 331,937 & $3.027 \mathrm{e}+07$ \\
\hline & $(1.445 \mathrm{e}+08)$ & $(6.189 e+07)$ \\
\hline \multirow[t]{2}{*}{ Largest } & $-46,268$ & 572,525 \\
\hline & $(1.359 \mathrm{e}+06)$ & $(788,142)$ \\
\hline \multirow[t]{2}{*}{$\operatorname{lnBoard}$} & $5.860 \mathrm{e}+07$ & $-4.686 e+07$ \\
\hline & $(8.972 \mathrm{e}+07)$ & $(4.850 \mathrm{e}+07)$ \\
\hline \multirow[t]{2}{*}{ Indep } & $1.565 \mathrm{e}+08$ & $-9.858 \mathrm{e}+07$ \\
\hline & $(2.283 \mathrm{e}+08)$ & $(1.914 \mathrm{e}+08)$ \\
\hline \multirow[t]{2}{*}{ FthreeExComp } & $53.89 * * *$ & 8.227 \\
\hline & $(8.593)$ & (24.08) \\
\hline \multirow[t]{2}{*}{ Mhold } & $7.475 \mathrm{e}+08$ & $5.969 \mathrm{e}+10$ \\
\hline & $(1.519 \mathrm{e}+09)$ & $(7.689 \mathrm{e}+10)$ \\
\hline Industry & Yes & Yes \\
\hline Year & Yes & Yes \\
\hline \multirow[t]{2}{*}{ Constant } & $1.483 \mathrm{e}+10^{* * *}$ & $5.550 \mathrm{e}+09 * * *$ \\
\hline & $(5.283 e+09)$ & $(1.489 e+09)$ \\
\hline
\end{tabular}

Standard errors in parentheses

$* * * \mathrm{p}<0.01, * * \mathrm{p}<0.05, * \mathrm{p}<0.1$

4.3.2 High versus Low Financial Leverage

Managerial excess perks exist on the basis of much free cash flows in the firms. When the firms have more free cash flows, the managers have motivation to spend the funds for increasing their own private interests. Higher level of 
financial leverage will increase the amounts of free cash flows. This paper finds that the effect of accounting conservatism constraining managerial excess perks is significant in statistics when the firms have more financial debts. However, this relationship is not significant when the firms borrow less debts. In order to classify the different levels of financial leverage in the listed firms, firstly, the percentiles of control variable Lev are solved. Then, any firm that Lev is more than 0.8005437 (90\% percentiles) belongs to higher level of financial leverage; any firm that Lev is less than 0.3868041 (25\% percentiles) is considered as lower level of financial leverage. In the table 5, the column (1) shows the negative relationship between CONSER_Score and AbnormalPerk when the firms have higher financial leverage. The significant level is $99 \%(\mathrm{p}<0.01)$. The coefficient of testable variable CONSER_Score is $-6.781 \mathrm{e}+10$. But this paper cannot find the significant relationship when the financial level is lower based on the data in column (2).

Table 5. Regression Analysis

\begin{tabular}{|c|c|c|}
\hline VARIABLES & $\begin{array}{c}(1) \\
\text { AbnormalPerk } \\
\text { High Leverage }\end{array}$ & $\begin{array}{c}\text { (2) } \\
\text { AbnormalPerk } \\
\text { Low Leverage }\end{array}$ \\
\hline CONSER_Score & $\begin{array}{c}-6.781 \mathrm{e}+10^{* * *} \\
(2.516 \mathrm{e}+10)\end{array}$ & $\begin{array}{l}-1.185 e+10 \\
(8.134 e+09)\end{array}$ \\
\hline Size & $\begin{array}{c}-6.097 \mathrm{e}+08 * * \\
(2.640 \mathrm{e}+08)\end{array}$ & $\begin{array}{l}-2.402 \mathrm{e}+07 \\
(8.729 \mathrm{e}+07)\end{array}$ \\
\hline CFORatio & $\begin{array}{c}3.203 e+08 \\
(2.208 e+08)\end{array}$ & $\begin{array}{c}2.163 \mathrm{e}+06 \\
(1.124 \mathrm{e}+07)\end{array}$ \\
\hline SalesGrowth & $\begin{array}{c}5.577 \mathrm{e}+06 \\
(7.762 \mathrm{e}+06)\end{array}$ & $\begin{array}{c}1.805 \mathrm{e}+06 \\
(2.128 \mathrm{e}+06)\end{array}$ \\
\hline Lev & $\begin{array}{c}3.679 \mathrm{e}+09 * * * \\
(1.356 \mathrm{e}+09)\end{array}$ & $\begin{array}{c}5.372 \mathrm{e}+08 \\
(4.489 \mathrm{e}+08)\end{array}$ \\
\hline State & $\begin{array}{c}1.112 \mathrm{e}+07 \\
(6.666 \mathrm{e}+07)\end{array}$ & $\begin{array}{l}-6.240 e+06 \\
(2.489 e+07)\end{array}$ \\
\hline $\ln \mathrm{Age}$ & $\begin{array}{c}5.726 \mathrm{e}+07 \\
(2.210 \mathrm{e}+08)\end{array}$ & $\begin{array}{l}1.225 \mathrm{e}+08^{*} \\
(7.142 \mathrm{e}+07)\end{array}$ \\
\hline Largest & $\begin{array}{c}2.809 \mathrm{e}+06 \\
(2.592 \mathrm{e}+06)\end{array}$ & $\begin{array}{c}597,211 \\
(843,464)\end{array}$ \\
\hline $\operatorname{lnBoard}$ & $\begin{array}{c}4.224 \mathrm{e}+07 \\
(1.711 \mathrm{e}+08)\end{array}$ & $\begin{array}{l}-2.847 \mathrm{e}+07 \\
(5.337 \mathrm{e}+07)\end{array}$ \\
\hline Indep & $\begin{array}{c}8.725 e+07 \\
(5.479 e+08)\end{array}$ & $\begin{array}{c}2.118 \mathrm{e}+08 \\
(1.516 \mathrm{e}+08)\end{array}$ \\
\hline FthreeExComp & $\begin{array}{c}46.97 \\
(35.74)\end{array}$ & $\begin{array}{c}58.50 * * * \\
(7.931)\end{array}$ \\
\hline Mhold & $\begin{array}{l}-1.830 \mathrm{e}+10 \\
(2.048 \mathrm{e}+10)\end{array}$ & $\begin{array}{c}3.292 \mathrm{e}+08 \\
(5.118 \mathrm{e}+08)\end{array}$ \\
\hline Constant & $\begin{array}{l}1.314 \mathrm{e}+10 * * \\
(5.982 \mathrm{e}+09)\end{array}$ & $\begin{array}{c}2.336 \mathrm{e}+08 \\
(1.935 \mathrm{e}+09)\end{array}$ \\
\hline Industry & Yes & Yes \\
\hline Year & Yes & Yes \\
\hline Observations & 134 & 363 \\
\hline Number of ID & 60 & 134 \\
\hline
\end{tabular}

Standard errors in parentheses

$* * * \mathrm{p}<0.01, * * \mathrm{p}<0.05, * \mathrm{p}<0.1$ 


\section{Conclusions}

Firms' compensation consists of explicit compensation, such as salary or bonus, etc. and implicit compensation, such as promotion or managerial perks. Perks are defined as the nonmonetary compensation for selected employees. However, above normal standards perks would erode the value of firms and reduce the interests of shareholders. Prior researches have investigated that the extent of marketization、 the firm's ownership and corporate governance matter for the managerial excess perks. This paper is based on the selected listed firms in China. This research concludes that accounting conservatism can restrict managerial excess perks. This effect would be even higher when the firms are state owned enterprises. In the robustness tests, the results also testify the negative relationship between accounting conservatism and managerial excess perks. Furthermore, the results find that the effects are even stronger in the firms of lower level accounting conservatism and higher level of financial leverage. It suggests that accounting conservatism really matters for the managerial excess perks especially in the firms of the state ownership, lower level of accounting conservatism and higher level of financial leverage.

\section{References}

Adithipyangkul, P., I. Alon, \& T. Zhang. (2009). Executive perks: compensation and corporate performance in China. Asia Pacific Journal of Management, 28, 401-425. https://doi.org/10.1007/s10490-009-9162-3

Andrews, A., S.C. Linn, H.Yi. (2009). Corporate governance and executive perquisites: evidence from the new SEC disclosure rules. Working Paper.

Baker, G.P., M.C. Jensen, \& K.J. Murphy. (1987). Compensation and Incentives: practice vs. theory. The Journal of Finance, 43(3), 593-616. https://doi.org/10.1111/j.1540-6261.1988.tb04593.x

Beekes, W., P. Pope, \& S. Young. (2004). The link between earnings timeliness, earnings conservatism and board composition: evidence from the U.K. Corporate Governance: An International Review, 12(1), 47-59. https://doi.org/10.1111/j.1467-8683.2004.00342.x

Basu, S. (1997). The conservatism principle and the asymmetric timeliness of earnings. Journal of Accounting and Economics, 24(1), 3-37. https://doi.org/10.1016/S0165-4101(97)00014-1

Basu, S. L. Hwang, \& C. Jan. (2001a). Auditor conservatism and quarterly earnings. Working paper. Baruch College-CUNY.

Cai, H., H. Fang, L.C. Xu. (2011). Eat, drink, firms, government: an investigation of corruption from the entertainment and travel costs of Chinese firms. Journal of Law and Economics, 54, 55-78. https://doi.org/10.1086/651201

Chen, D., X. Chen, \& H. Wan. (2005). Regulation and non-pecuniary compensation in Chinese SOEs. Economic Research Journal, 2, 92-101.

Easterbrook, F.H. (1984). Two agency-cost explanations of dividends. American Economic Review, 74, 650-659.

Fama, E.F. (1980). Agency problems and the theory of the firm. Journal of political economy, 88(2), 288-307. https://doi.org/10.1086/260866

Francis, J., R.Z. LaFond, P. Olsson, \& K. Schipper. (2004). Costs of capital and earnings attributes. The Accounting Review, 70, 967-1010. https://doi.org/10.2139/ssrn.414125

Givoly, D., \& C. Hayn. (2000). The changing time-series properties of earnings, cash flows and accruals: has financial reporting become more conservative? Journal of Accounting and Economics, 29(3), 287-320. https://doi.org/10.1016/S0165-4101(00)00024-0

Givoly, D., C.K. Hayn, \& A. Natarajan. (2007). Measuring reporting conservatism. The Accounting Review, 82(1), 65-106. https://doi.org/10.2308/accr.2007.82.1.65

Gul, F.A., B. Srinidhi, \& T. Shieh. (2002). The Asian financial crisis, accounting conservatism and audit fees: Evidence from Hong Kong. Working paper. City University of Hong Kong.

Hao, Y., G. Xie, \& R. Shi. (2018). External supervision, perquisite consumption and enterprise performance. Accounting Research, 8, 42-48 (in Chinese).

Hart, O.D. (2001). Financial contracting. Journal of Economic Literature, 39, 1079-1100. https://doi.org/10.1257/jel.39.4.1079

Jensen, M.C. (1986). Agency costs of free cash flow. Corporate finance and takeovers. American Economic Review, 76(2), 323-329. 
Jensen, M., \& W. Meckling. (1976). Theory of the firm: Managerial behavior, agency costs and ownership structure. Journal of Financial Economics, 3, 305-360. https://doi.org/10.1016/0304-405X(76)90026-X

Krishnan, G., \& G. Visvanathan. (2008). Does the SOX definition of an accounting expert matter? The association between audit committee directors' accounting expertise and accounting conservatism. Contemporary Accounting Research, 25(3), 827-858. https://doi.org/10.1506/car.25.3.7

Luo, H., \& W. Huang. (2008). Dividend payout in SOEs、managerial perks and corporate performance. Management World, 9,139-148 (in Chinese).

Luo, W., Zhang, Y. \& Zhu, N. (2011). Bank Ownership and Executive Perquisites: New Evidence from an Emerging Market. Journal of Corporate Finance, (17), 352-370. https://doi.org/10.1016/j.jcorpfin.2010.09.010

Merriam-Webster's collegiate dictionary (11th ed.). (2004). Springfield, MA: Merriam-Webster.

Rajan, R. G., \& J. Wulf. (2006). Are perks purely managerial excess? Journal of Financial Economics, (79), 1-33. https://doi.org/10.1016/j.jfineco.2005.01.003

Rozeff, M. (1982). Growth, beta and agency costs as determinants of dividend payout ratios. Journal of Financial Research, 5, 249-259. https://doi.org/10.1111/j.1475-6803.1982.tb00299.x

Yermack, D. (2006). Flight of fancy: corporate jets, CEO perquisites, and inferior shareholder returns. Journal of Financial Economics, 80, 211-242. https://doi.org/10.1016/j.jfineco.2005.05.002

Zhai, S., Y. Xu, \& D. Yang. (2015). Can media supervise state-owned enterprise executives nor-pecuniary compensation? Accounting Research, 5, 57-95 (in Chinese).

Zhang, H., Y. Song, \& Y. Ding. (2015). What drives managerial perks? An empirical test of competing theoretical perspectives. Journal of Business Ethics, 132, 259-275. https://doi.org/10.1007/s10551-014-2320-7

\section{Notes}

Note 1. In the Chinese accounting standards and International Accounting standards, research costs can be expensed at once and development costs should be capitalized under 5 conditions. However, in USA, all research and development costs should be expensed at financial reporting year. This paper applies for Chinese accounting standards. 